\title{
The Impact of Cyberbullying on the Self- Esteem and Academic Functioning of Arab American Middle and High School Students
}

\author{
Wael Shaher Mohammed Yousef ${ }^{1}$
}

\&

Al Bellamy ${ }^{2}$

${ }^{1}$ College of Technology, Eastern Michigan University Ypsilanti, Michigan

${ }^{2}$ School of Technology Studies, Eastern Michigan University Ypsilanti, Michigan

USA

Correspondence: Al Bellamy. School of Technology StudiesEastern Michigan University Ypsilanti, Michigan 48197.USA. E-mail: al..bellamy@emich.edu

(C) Education \& Psychology I+D+i and Ilustre Colegio Oficial de la Psicología de Andalucía Oriental (Spain) 


\section{Abstract}

Introduction. Cyberbullying has received a considerable amount of attention within the academic and public literature. However, very little if any cyberbullying research has been conducted among Arab American students. This current study explored the impact of cyberbullying among middle and high school Arab American students on their self-esteem and academic functioning. It further explored the extent to which levels of emotional intelligence moderated these relationships.

Method. The population of this study consisted of 1,152 middle and high school students, grades 6 through 12 from four different charter schools in Wayne County in Michigan. These schools represented different ethnic groups, such as Arab Americans, African Americans, Hispanic and White.

Results. The results of the study indicate that Arab Americans experience more cyberbullying than the other ethnic groups within the study. The data illustrates that cyberbullying has an expected negative effect on student self-esteem and academic functioning among the Arab American group. There were mixed findings among the other ethnic student groups.

Discussion. The level of student emotional intelligence was shown to moderate the relationships between cyberbullying, self-esteem and academic functioning more-so among Arab Americans than for the African American and White American student groups. This finding informs school practitioners that it would be advantageous to develop programs that promote emotional intelligence among students.

Keywords: Cyberbullying, Arab Americans, Academic Functioning, Emotional Intelligence 


\section{El impacto del ciberbullying sobre la autoestima y el rendimiento académico de estudiantes árabe-americanos de Secundaria Resumen}

Introducción. El acoso cibernético ha recibido una considerable atención en la literatura académica y pública. Sin embargo, muy poca o ninguna investigación de acoso cibernético se ha realizado entre los estudiantes estadounidenses árabes. Este estudio exploró el impacto de ciberacoso entre la escuela media y secundaria los estudiantes americanos árabes en su autoestima y el funcionamiento académico. Se exploró también el grado en que los niveles de inteligencia emocional moderados estas relaciones.

Método. La población de este estudio consistió en 1.152 estudiantes de secundaria y preparatoria, grados 6 al 12 de cuatro escuelas diferentes en el Condado de Wayne en Michigan (USA). Estas escuelas representan diferentes grupos étnicos, como los árabes americanos, los afroamericanos, los hispanos y los blancos.

Resultados. Los resultados del estudio indican que los árabes estadounidenses sufren más acoso cibernético que los otros grupos étnicos dentro del estudio. Los datos ilustran que el acoso cibernético tiene un efecto negativo esperado en la auto-estima y funcionamiento académico entre el grupo estadounidense de origen árabe. Hubo resultados mixtos entre los otros grupos de estudiantes étnicos.

Discusión. El nivel de inteligencia emocional estudiante se mostró a moderar las relaciones entre el acoso cibernético, la autoestima y el funcionamiento académico más así entre los estadounidenses árabes que para los grupos de estudiantes estadounidenses y negro afroamericanos. Este hallazgo informa practicantes escolares que sería ventajoso desarrollar programas que promuevan la inteligencia emocional de los estudiantes.

Palabras clave: ciberbullying, árabes estadounidenses, el funcionamiento académico, inteligencia emocional 


\section{Introduction}

Cyberbullying has received a considerable amount of attention within the academic and public literature (Agatston, Kowalski, \& Limber, 2007; Beran and Li, 2005; Hindujia \& Patchin, 2008; Ybarra, \& Mitchell, 2007; Patchin \& Hinduja, 2012) within the United States. It has drawn recent empirical attention in China (Zhou et. al, (2013; Finland (Williford, et.al., (2013) and Australia (Sakellianou, et. al, (2012) as well as among other nations. Holfeld and Grabe, (2012) in a study of middle school students reported that $55 \%$ of their sample of students had experienced some form of cyber bullying.Olweus (1993) defined bullying as "A person is bullied when he or she is exposed, repeatedly and over time, to negative actions on the part of one or more other persons, and he or she has difficulty defending himself or herself" Olweus (p. 9). Cyber bullying has been defined as: "willful and repeated harm inflicted through the use of computers, cell phones, and other electronic devices" (Hinduja \& Patchin, 2009, p. 5). It also has been defined by the Belsey, (2000) as "The use of information and communication technologies to support deliberate, repeated, and hostile behavior by an individual or group that is intended to harm others" (P. 1). Ybarra and Mitchell (2004b) defined cyber bullying as "an overt, intentional act of aggression towards another person online" (p. 1308).

The relationship between cyber bullying experiences among Arab American students and their self-esteem and academic functioning in middle and high schools has received very little attention within the research literature. The United State of America has "the largest immigrant population in the world, indeed in world history," which contributes to making American society "one of the world's largest multiethnic societies" (Schuchman, 1997). Arab Americans are one of these multi ethnic groups coming from multiple Arab countries such as Yemen, Iraq, Saudi Arabia, Palestine, Lebanon, Jordan, Oman, Tunisia, Egypt, Sudan, Kuwait, United Arab Emirate, Algeria, Bahrain, Libya, Syria, Qatar, and Morocco. According to the U.S. Census in 2000, there are 1.2 million Arabs in the U.S. Today there are many more.

The purpose of the current study was to determine the extent to which Arab American students in middle and high school experience cyber bullying, and the extent that cyber bullying is related to self-esteem and academic functioning. The study further explored the extent to which emotional intelligence moderates the relationship between levels of bullying 
and academic functioning and self-esteem. The research also includes data collected from students from three other cultural backgrounds: African American, White and Hispanics. Comparative data between these three groups and the data from Arab American students enabled the researchers to determine similarities and differences between ethnic groups in their response to cyber bullying experiences. Data for this study was gathered from middle and high school students attending schools in a large metropolitan area.

Many of the Arab students arrive in the U.S. with language barriers, culture shock and may have experienced turmoil in their country of origin. These circumstances in and of themselves put psychological stress upon these students. Add to this the availability of the internet and the potential for cyber bullying and one finds a potentially toxic school environment that can have a tremendous impact on student self-esteem and academic functioning. Electronic intimidation is possible today because of the ready availability of a large number of digital communication technologies and social media websites, and occurs both inside and outside of school. Students are no longer safe in their own homes; these technologies extend the destructive reach of the bully. Because the United States has experienced a steady increase in immigration and the numbers of ethnic groups attending public schools, it is increasingly important for school systems to have up to date information about cyber bullying in order to avoid any additional stress on these newly arriving students.

During the teenage years, students are in a stage of development where they are developing their own specific identity (Sullivan, Clearly, \& Sullivan, 2004). Socializing is almost an obsession during this time period and teasing is often a part of the socializing experience. Teasing is oftentimes viewed as a harmless way for students to test their identities and the identities of their peers. Students may accept the teasing and laugh it off or become defensive if the teasing offends their identity. Sometimes the teasing can escalate to cyberbullying.

The paper will proceed in the following manner; we first present the conceptual frameworks of the study. We will then proceed with the research questions, research methodology, a report of the results and then a summarizing discussion. 


\section{Conceptual Frameworks of Study}

\section{Impairment of Academic Functioning}

The researchers Glew, Fan, Katon, Rivara, and Kernic (2005) stated that victims and bullies are low performers in school, while other researchers found that poor peer relationships during adolescents affect children's academic performance (Patchin and Hinduja, 2007). Schwartz, Gorman, Nakamota, and Toblin (2005) also pointed out that peer adolescent relationships and cyber bullying in school could negatively affect students' academic performance. Graham, Bellmore, and Juvonen (2003) stated that low academic performance and skipping school is due to traditional bullying among adolescents.

Graham et al. (2003) surveyed 785 students from sixth grade to eighth grade. The results of the study indicated that the victims of bullying had less interest in school than other students. Also Nansel, Haynie, and Simons-Morton (2003) stated that students who were involved in bullying and victimization were not interested in school and less engaged in academics. According to the National Association of School Psychologists, some students skipped school each day because they had fears of being bullied. Glew et al. (2005) also stated that bullying affects academic achievement. David-Ferdon and Hertz (2007) stated that students who were involved in cyber bullying as a victim or perpetrator were often struggling in school with academic performance. According to the National Center for Mental Health Promotion and Youth Violence Protection (2009), students who were victims of cyber bullying start to struggle in their homework and become unenthusiastic about attending school.A study conducted by Raskauskas and Stoltz (2007) stated that $31 \%$ of students who were cyber bully victims reported that they are emotionally upset. They also stated that $19 \%$ of the students of cyber bully victims were extremely afraid, whereas $18 \%$ of them were very embarrassed about online harassment. They concluded that students who experience cyber bullying behaviors fall behind in school and some even drop out of school.

According to Tippett, Thompson, and Smith (2009), cyber bullying caused more harm to the students than does traditional bullying because as the use of pictures and video clips give the bully more options for tormenting the victim Students who experience cyber bullying usually suffer from depression and anxiety. They do not like to go to school and 
their performance declines. They usually show anger or fear and avoid playing with their friends (Patchin \& Hinduja, 2007; Willard, 2006; Ybarra \& Mitchell, 2004a).

\section{Emotions and Emotional Intelligence}

Salovey and Mayer (1990) defined emotional intelligence as "the ability to monitor one's own and others' emotions, to discriminate among them, and to use the information to guide one's thinking and actions" (p. 189). Mayer and Salovey (1997) defined it again as:

The capacity to reason about emotions, and the use of emotions to enhance thinking. It includes the abilities to accurately perceive emotions, to access and generate emotions so as to assist thought, to understand emotions and emotional knowledge, and to reflectively regulate emotions so as to promote emotional and intellectual growth (p. 197)

Online activities and interactions can heighten the emotions (Walther, 1997). According to Finn (2004), the internet can create a misunderstanding of intentions, and a misleading of the sense of relationship. Alderman (2001) indicated that bullying targets may blame themselves, and, according to Willard (2007), bullying targets believe that they deserve to be bullied and harassed, both in school and online.

Cyber bullying has many consequences such as depression, anxiety, and negative social views of oneself. (Grene, 2003; Juvonen et al., 2003; Olweus, 1999) (Cetin et. al. 2012)(Patchin and Hinduja (2007) stated in their study that $54 \%$ of cyber bully victims were negatively affected in some way, such as feeling frustration, madness, or distress. Several studies have expressed their concern with the negative emotions resulting from cyberbullying, which often has been resolved youth through self-destructive behaviors, violence between individuals and various forms of deviance (Borg 1998; Ericson, 2001; Rigby 2003; Roland 2002; Seals and Young, 2003). Litwiller \& Brausch (2013) in a study among adolescents delineated violent behavior and substance abuse as mediating factors of the relationships between cyberbullying and suicidal behaviors.

The impact of cyber bullying, as stated by Breguet (2007), is that the cyber bully victims are often friendless, lack confidence, and feel humiliated. Consequently, cyber bully 
victims often suffer from lowered self-esteem, hopelessness, depression and withdrawal (Patchin and Hinduja, 2007; Strom and Strom, 2005b).

Given the attention that has been given to emotions within the literature, particularly as it pertains to educational processes (Bellamy, Gore, \& Sturgis, 2005; Pegalajar, Carmen, \& Colmenero-Ruiz, 2014); Yusoff, \& Zin, 2013), this study wanted to investigate if a student's level of emotional intelligence affected the impact of bullying on academic functioning. We are advancing the theoretical proposition that the correlation between levels of cyberbullying and perceptions of academic functioning as well as self-esteem would be weaker for students of lower emotional intelligence. An important practical implication extending from the confirmation this proposition would be to develop mechanisms within the context of the education process to enhance the emotional intelligence of students.

\section{Self Esteem}

Based upon the vast amount of literature that has documented the effect of selfesteem(Hadwin and Webster, 2013;Pavandeh, et. al., 2013) and on academic achievement, we felt that it was equally important to examine the effect that cyberbullying has on selfesteem, particularly among Arab American students. (Rosenberg, 1965), defined self-esteem as "a positive or negative attitude toward particular objects, namely, the self" (p. 30). Several studies have described the negative influence of cyberbullying on self-esteem. A study conducted by O'Moore and Kirkham (2001) on students in Ireland found that students who had been victims of bullying had lower self-esteem than students who had not been bullied; whereas, students who had not been involved in bullying had higher self-esteem than bullies. Patchin and Hinduja (2007) pointed out that self-esteem can be damaged by experiencing cyber bullying. Craig (1998), Kowalski and Limber (2007), and Ybarra and Mitchell (2004), stated that cyber bullies and their victims showed lower self-esteem than bullies or students not involved in cyber bullying. Meta-analysis research was conducted on bullying by Hawker and Boulton, (2000). Their analysis revealed that victims of bullying are more depressed and had lower self-esteem than their non-bullied peers.: Sampasa-Kanyinga et.al.,(2014) in a study of Canadian middle and high school students described the breakfast skipping as a negative outcome of cyberbullying. 
According to Salmivalli (1998) victims of bullying have low self-esteem because they blame themselves for attacks and being failures. Students, who have low self-esteem usually find difficulty in making friends, and tend to become isolated and lonely at school (Olweus, 1993c). Olweus (1993a),proposed that the individuals who have low self-esteem usually are unconfident, ignored and have unbalanced emotions. Studies conducted by Hunt (2012 and Modecki et. al (2013), also revealed a negative relationship between cyberbullying and victim self-esteem.

\section{Research Questions}

1. What are the differences among Arab American, White, Black and Hispanic American students in their frequency of being bullied?

2. What is the relationship between cyberbullying and academic functioning and selfesteem among Arab American Students?

3. To what degree is the correlations between cyberbullying, self-esteem, and academic functioning different or similar among students of other ethnic groups and Arab Americans?

4. To what extent does emotional intelligence moderate the relationship between cyberbullying and academic functioning and self-esteem among Arab American Students?

5. To what extent does emotional intelligence moderate the relationship between cyberbullying and academic functioning and self-esteem among students of other ethnic groups?

Figure 1 describes the conceptual model of the study. 


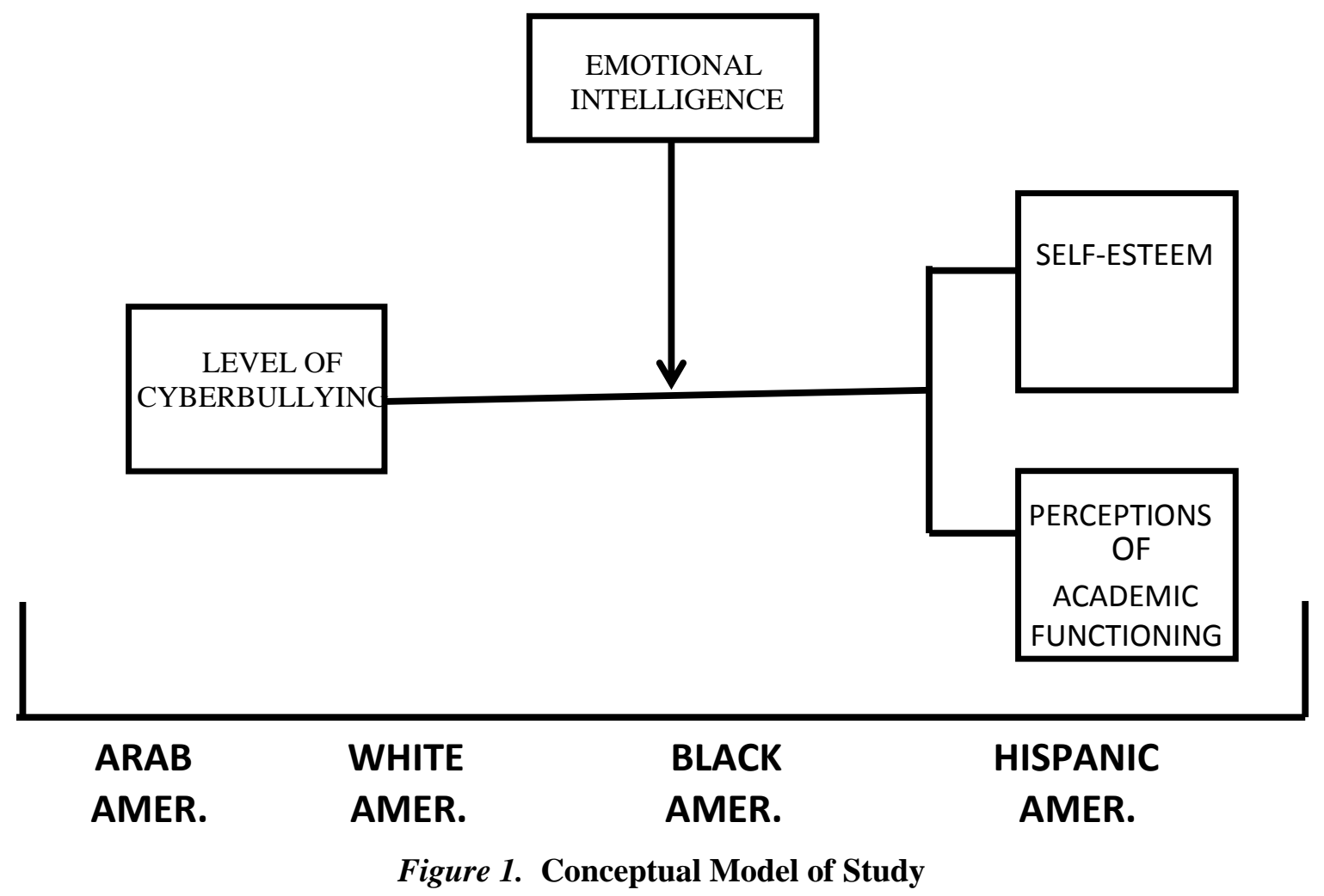

\section{Method}

\section{Participants}

This study was conducted among 1,030 middle and high school students within Arab American charter schools located in a large Midwestern metropolitan area. These schools were relatively diverse in regards to ethnicity. Table 1. describes the ethnicity/race distribution within the study.Since the largest groups were Arab Americans, White American, African-American and Hispanic American, the data analysis of this study are confined to these four ethnic groups. The study consisted of 442 males and 588 females. Table 2 illustrates the grade distribution. 
Table 1. Ethnicity/Race Distribution

\begin{tabular}{lrr}
\hline & Number & Percent \\
\hline Arab American & 367 & 35.6 \\
Bangladeshi & 4 & 0.4 \\
Indian & 13 & 1.3 \\
Pakistani & 2 & 0.2 \\
African-American & 155 & 15.0 \\
White American & 358 & 34.8 \\
Hispanic American & 110 & 10.7 \\
Native American/Native & 13 & 1.3 \\
Alaskan & 8 & 0.8 \\
Others & & 100.0 \\
Total & 1,030 & \\
\hline
\end{tabular}

Table 2. Grade distribution

\begin{tabular}{|c|c|c|}
\hline Grade & Number & Percent \\
\hline 6 & 130 & 12.6 \\
\hline 7 & 159 & 15.4 \\
\hline 8 & 185 & 18.0 \\
\hline 9 & 212 & 20.6 \\
\hline 10 & 121 & 11.7 \\
\hline 11 & 134 & 13.0 \\
\hline 12 & 89 & 8.6 \\
\hline Total & 1,030 & 100.0 \\
\hline
\end{tabular}

\section{Instrumentation}

The researcher used a survey tool, which consists of four scales: a Cyber Bullying Scale, a Self-Esteem Scale, an Emotional Intelligence Scale (EQ), and The Impact on Career and Educational Function (ICEF) Scale (Linn, 1999). The questionnaire included four 
questions regarding the student's gender, school, grade, and ethnicity/race as well as 64 multiple choice questions about cyber bullying, self-esteem, emotional intelligence and academic functioning. The entire survey included 68 questions.

\section{Smith, Mahdavi, Carvalho, and Tippett Cyber Bullying Scale}

The researchersutilized a modified version of the Cyber Bullying Scale that was developed by Smithet al. (2006). The modified version consisted of 13 items which asked students to describe the frequency in which they had been cyberbullied inside and outside of school during the past 3 months. The scale also included questions regarding other aspects of bullying such as identifying the bully. This study, however, will focus on the frequency of bullying questions which consisted of format that queried the frequency of being bullied.The responses were ranked on a scale from 0 to 4 with 0 meaning the respondents had never been cyber bullied and 4 meaning the respondents had been cyber bullied as much as several times per week. The Chronbach Alpha reliability for this scale was .90 for the present study.

\section{Rosenberg's Self-Esteem Scale}

The Rosenberg's Self-Esteem Scale, (1965) was used to identify levels of student self-esteem. This scale consisted of 10 items utilizing a Likert-type format of: $1=$ strongly agree, $2=$ agree, $3=$ disagree , and $4=$ strongly disagree. The Chronbach Alpha reliability of the scale within the present study was .72.

\section{Schutte's Emotional Intelligence Scale}

The Schutte's Emotional Intelligence Scale, (1998)used to measure students' emotional intelligence. This scale consisted of 33 itemsutilizing a five-point response scale. The Chronbach Alpha for the scale was .94.

\section{Impairment of Academic Functioning Scale}

The Impact on Career and Educational Functioning (ICEF) Scale (Linn, 1999) was utilized to measure impairment of academic functioning. This scale consists of 18 items. A modified version consisting of 8 items was used for the current study. The scale items were rated on a 5 -point Likert scale $0=$ not at all, $1=$ a little bit, $2=$ some, $3=$ quite a bit, and $4=$ most of the time. This scale revealed a Chronbach alpha reliability score of .60 . 


\section{Procedure}

The survey was implemented through Survey Monkey. Students were required to submit a consent to participate form. Permission to implement the survey was gathered from each of the participating high schools.

\section{Data analysis}

Data collected via Survey Monkey was transferred to the Statistical Package for the Social Sciences (SPSS) software. Data was analyzed utilizing the Pearson Moment Correlation procedure along with descriptive statistics.

\section{Results}

1. What are the differences among Arab American, White, Black and Hispanic American students in theirfrequency of being bullied?

As revealed in Table 3, Arab Americans reported the highest number of times being cyberbullied while in school (42\%) followed by White American students. Each of these two groups also reported the highest level of cyberbullying outside of school with White American students reporting $42 \%$ and Arab Americans reporting 41\% respectively. What is interesting about these findings is that African and Hispanic American students report significantly lower rates of cyberbullying within both categories.

Table 3. Number of Times Students Have Been Cyber Bullied Victims In and Outside of School

\begin{tabular}{lrrrrrrrr}
\hline & \multicolumn{3}{c}{ Cyber Bully In School } & \multicolumn{3}{c}{ Cyber Bully Outside of School } \\
\cline { 2 - 8 } \multicolumn{1}{c}{ Ethnicity } & $N$ & $\%$ & Mean & $\begin{array}{c}\text { Standard } \\
\text { Deviation }\end{array}$ & $N$ & $\%$ & Mean & $\begin{array}{c}\text { Standard } \\
\text { Deviation }\end{array}$ \\
\hline Arab American & 157 & 42.0 & 2.92 & 1.06 & 97 & 41.0 & 2.71 & 1.00 \\
$\begin{array}{l}\text { African- } \\
\text { American }\end{array}$ & 50 & 13.0 & 3.14 & 1.16 & 17 & 7.0 & 2.76 & 1.03 \\
$\begin{array}{l}\text { White American } \\
\text { Hispanic }\end{array}$ & 125 & 33.0 & 2.89 & 1.01 & 101 & 42.0 & 2.41 & 0.79 \\
American & 43 & 12.0 & 2.88 & 1.05 & 24 & 10.0 & 2.50 & 0.98 \\
Total & 375 & 100.0 & 2.94 & 1.05 & 239 & 100.0 & 2.59 & 0.94 \\
\hline
\end{tabular}


2. What is the relationship between cyberbullying and academic functioning and self-esteem among Arab American Students?

The results in Table 4 reveal that cyberbullying has a moderate and statistically significant effect on both self-esteem and academic functioning among Arab American students. The direction of the relationships is negative indicating that increases in cyberbullying are associated with a decrease in self-esteem and academic functioning for both categories of cyberbullying.

Table 4. Correlations Between Cyber Bullying and Self Esteem and Academic Functioning Moderated By High and Low Emotional Intelligence

How often have you been

Cyber bullied in school the past 3 months?
How often have you been cyber bullied out of school the

Past three months?

\begin{tabular}{|c|c|c|c|c|}
\hline & Self-Esteem & Academ. Funct. & Self-Esteem & Academ. Funct. \\
\hline \multicolumn{5}{|c|}{ Arab Amer. Students $(\mathrm{n}=367)$} \\
\hline Low EQ & $-.276^{* *}$ &.$-261^{* *}$ & $-.205^{*}$ & $.233 * *$ \\
\hline High EQ & -.172 & .123 & $-.282 * *$ & .145 \\
\hline \multicolumn{5}{|c|}{ White Amer. Students $\quad(\mathrm{n}=358)$} \\
\hline Low EQ & -.225 & .213 & -.103 & -.060 \\
\hline High EQ & .124 & -.076 & -.078 & .110 \\
\hline \multicolumn{5}{|c|}{ Afro. Amer. Students $\quad(\mathrm{n}=155)$} \\
\hline Low EQ & -.125 & .079 & -.154 & .313 \\
\hline High EQ & -.140 & $.276^{* *}$ & -.103 & -.058 \\
\hline \multicolumn{5}{|c|}{ Hispanic Amer. Students $(\mathrm{n}=110)$} \\
\hline Low EQ & $-.325^{*}$ & -.057 & $-.337 *$ & .196 \\
\hline High EQ & $-.323^{*}$ & $-.388^{*}$ & -.236 & -.069 \\
\hline
\end{tabular}

$\overline{* p} \leq .05 \quad * * p \leq .00 \quad$ Two-tailed

3. To what degree are the correlations between cyberbullying, self-esteem, and academic functioning different or similar among students of other ethnic groups and Arab Americans?

Table 4 illustrates that the only ethnic group that has statistically significant correlations between cyberbullying, self-esteem and academic functioning for both cyberbullying categories is the Arab American student group. The White American and 
African student groups only reveal statistically significant correlations within one cyberbullying category. There is positive correlation between in school bullying and academic functioning among the African American students which indicates that higher levels of cyberbullying leads to higher academic functioning among this group students. This is a very surprising finding. The Hispanic American student group reveals the strongest correlations between cyberbullying, self-esteem, and academic functioning. However, this finding is found only within the cyberbullying while in school category.

4. To what extent does emotional intelligence moderate the relationship between cyberbullying and academic functioning and self-esteem among Arab American Students?

Table 4 presents some interesting findings regarding the extent to which the level of emotional intelligence among Arab Americans impacts the relationships between cyberbullying, self-esteem, and academic functioning. Relatively moderate and statistically significant correlations are revealed among all of the variables for both categories of cyberbullying among Arab American students with low emotional intelligence. The correlations within the cyberbullying within school category are stronger than those revealed for the direct correlations among Arab American students. However, only onestatistically significant correlation is shown (self-esteem within the out of school category) among students with high emotional intelligence.This indicates that high emotional intelligence among Arab Students insulates them from the negative effects of cyberbullying, at least to a certain degree. This is particularly the case for in-school cyberbullying.

5. To what extent does emotional intelligence moderate the relationship between cyberbullying and academic functioning and self-esteem among students of other ethnic groups?

In comparison to the Arab American students (Table 4), the level of emotional intelligence among the White and Black American student groups does not moderate the relationship between cyberbullying and self-esteem and academic functioning. There are no statistically significant relationships revealed among the White student group and only one significant correlation among the Black American student group - cyberbullying in school and academic functioning. This correlation, however, is not substantially different from the direct correlation.For the Hispanic American student group on the other hand, there is a 
notable difference revealed between the direct and moderated correlations for the cyberbullying and academic functioning variables within the in-school cyberbullying category. The direct relationship indicates a relatively small and statistically insignificant correlation. The same correlation among the high emotional intelligence sub-category reveals a moderately strong and statistically significant negative correlation. This finding being revealed within the high emotional intelligence category is indeed surprising. This is contrary to the correlation found among the Arab American group.

\section{Discussion}

There are very few, if any, studies that have been conducted on the effect of Cyberbullying on the psychological and educational outcomes among Arab American students.The results of this current study indicate that Arab American students are indeed victims of cyberbullying.It further illustrates that the percentage of victims among Arab Americans is significantly higher than African American, White American and Hispanic students. Cyberbullying has been shown by previous studies conducted among Non-Arab American student groups to negatively affect student self-esteem and academic functioning. The current study illustrates that this is also the case among Arab American students. The findings of this study strongly suggest that other studies should be undertaken that utilize a qualitative methodological approach that would generate more substantial information regarding the 


\section{References}

Agatston, P. W., Kowalski, R., \& Limber, S. (2007). Students' perspectives on cyber bullying. Journal of Adolescent Health 41, 59-60

Alderman, L. (2001). Teens: How they become victims. Family PC, 76, 73-77.

Bellamy, A., Gore., Sturgis, J. (2005) Examining the relevance of emotional intelligence within educational programs for the gifted and talented. Electronic Journal of Research in Educational Psychology, 6(3), 58-78.

Beran, T., \& Li, Q. (2005). Cyber-harassment: A study of a new method for an old behavior. Journal of Educational Computing Research, 32(3), 265-277.

Borg, G. (1998). The emotional reaction of school bullies and their victims. Educational Psychology, 18(4), 433-444.

Breguet, T. (2007). Frequently asked questions about cyberbullying. New York, NY: The Rosen Publishing Group, Inc.

Cetin, B, Eroglu,Y, Peker, A; Akbaba, S, Pepsoy, S. (2012) The Investigation of Relationship among Relational-Interdependent Self-Construal, Cyberbullying, and Psychological Disharmony in Adolescents: An Investigation of Structural Equation Modelling. Educational Sciences: Theory and Practice, 12(2), 646-653.

Craig, W. M., \& Pepler, D. (2008). Introduction: Understanding and addressing bullying: An international perspective. Bloomington, IN: Authorhouse.

David-Ferdon, C., \&Hertz, M. F. (2007). Electronic media, violence, and adolescents: An emerging public health problem. Journal of Adolescent Health, 41, S1-S5.

Ericson, N. (June 2001). Addressing the problem of juvenile bullying. Fact Sheet \#200127. Washington, D.C.: Office of Juvenile Justice and Delinquency Prevention. Reprieved from https://www.ncjrs.gov/pdffiles1/ojjdp/fs200127.pdf

Finn, J. (2004). A survey of online harassment at a university campus. Journal of Interpersonal Violence, 19, 468-483.

Glew, G. M., Fan, M., Katon, W., Rivara, F. P., \& Y Kernic, M. A. (2005). Bullying psychosocial adjustment, and academic performance in elementary school. Archives of Pediatric Adolescent Medicine, 159, 1026-1031.

Grabe, M. (2012) Middle School Students' Perceptions of and Responses to Cyber Bullying. Journal of Educational Computing Research, 46(4), 395. 
Graham, S., Bellmore, A.,\& Juvonen, J. (2003). Peer victimization in middle school: When self- and peer views diverge. Journal of Applied School Psychology, 19, 117-137.

Grene, M. B. (2003). Counseling and climate change as treatment modalities for bullying in school. International Journal for the Advancement of Counselling, 25(4), 293-302.

Hadwin, A. F., Webster, A. (2013) Calibration in goal setting: Examining the nature of judgments of confidence. Learning and Instruction, 24, 37-47.

Hawker, D. S. J., \& Boulton, M. J. (2000). Twenty years' research on peer victimization and psychological maladjustment: A meta-analytical review of cross-sectional studies. Journal of Child Psychology and Psychiatry and Allied Disciplines, 41, 441-445.

Hunt, C. (2012) Development of a measure of the experience of being bullied in youth, Psychological Assessment, 24(1), 156-165.

Hinduja, S., \& Patchin, J. W. (2008). Cyberbullying: An exploratory analysis of factors related to offending and victimization. Deviant Behavior, 29 (2), 1-29.

Juvonen, J., Graham, S., \& Shuster, M. A. (2003). Bullying among young adolescents: The strong, the weak, and the troubled. Pediatrics, 112 (6), 1231-1237.

Kowalski, R. M., Limber, S. P., \& Agaston, P.W. (2008). Cyber bullying: Bullying in the digital age. Malden, MA: Wiley-Blackwell.

Litwiller, B., \& Brausch, A. (2013) Cyber Bullying and Physical Bullying in Adolescent

Suicide: The Role of Violent Behavior and Substance Use. Journal of Youth and Adolescence, 42 (5), 675-684.

Mayer J., \& Salovey P (1997) What is emotional intelligence? In: Salovey P and Sluyter D (Eds), Emotional Development and Emotional Intelligence: Implications for Educators (pp. 3-31). NewYork, NY: Basic Books,

Modecki, K., Barber, B., \& Vernon, L.(2013). Mapping developmental precursors of cyberaggression: Trajectories of risk prediction, perpetuation and victimization, Journal of Youth and Adolescence, 42 (5), 651-661.

Nansel, T. R., Haynie, D. L., \& Simons-Morton, B. G. (2003). The association of bullying and victimization with middle school adjustment. Journal of Applied School Psychology, 19, 45-61.

Olweus, D. (1991). Bully/victim problems among school children: Basic effects of a school based intervention program. In D. Pepler \& K. Rubin (Eds.), The Development and Treatment of Childhood Aggression (pp. 411-448). New Jersey: Erlbaum 
Olweus, D. (1993a). Bullying at school: What we know and what we can do. Cambridge, MA: Blackwell.

Olweus, D. (1999). In P. K. Smith, Y. Morita, J. Junger-Tas, D. Olweus, R. Catalano, \& P. Slee (Eds.). The nature of school bullying (pp. 7-27). London, England: Routledge.

O’Moore, M., \& Kirkham, C. (2001). Self-esteem and its relationship to bullying behavior. Aggressive Behavior, 27, 269-283.

Patchin, J. W., \& Hinduja, S. (2012). Cyberbullying: An update and synthesis of the research.

In J. Patchin \& S. Hinduja (Eds.), Cyberbullying prevention and response: Expert perspectives (pp. 13-35). New York: Routledge.

Payandeh, N, Amir T.; Najafabadi, M Farid-Rohani, Mohammad R. (2013). Factors contributing to academic achievement: A bayesian structure equation modeling study. International Journal of Mathematical Education in Science and Technology 44.4 490-500.

Pegalajar, P., Carmen, M., \& Colmenero-Ruiz, J. (2014) Emotional intelligence in secondary education students in multicultural contexts. Electronic Journal of Research in Educational Psychology. 12 (2) 0pp. 325-342.

Raskauskas, J., \& Stoltz , A. (2007). Involvement in traditional and electronic bullying among adolescents. Developmental Psychology, 43(3), 564-575.

Rigby, K., \& Slee, P. T. (1993). Dimensions of interpersonal relation among Australian children and implications for psychological well-being. The Journal of Social Psychology, 133(1), 33-42.

Roland, E. (2002). Bullying, depressive symptoms and suicidal thoughts. Educational Research 44, 55-67.

Rosenberg, M. (1965). Society and the adolescent self-image. Princeton, NJ: Princeton University Press.

Rosenberg, M. (1995). Global self- Esteem and specific self-esteem: Different concepts, different outcomes. American Sociological Review, 60, 141-156.

Salmivalli, C. (1998). Intelligence, attractive, well-behaving, Unhappy: The Structure of Adolescents' self-concept and its relation to their social behavior: Journal of Research on Adolescence, 8, 333-354

Salovey, P., \& Mayer, J. D. (1990). Emotional intelligence. Imagination, Cognition, and Personality, 9, 185-211. 
Sampasa-Kanyinga, H., Roumeliotis, P., Farrow, C.. (2014) Breakfast skipping is associated with cyberbullying and school bullying victimization. A school-based cross-sectional study, Appetite,79,76-82.

Smith, P., Mahdavi, J., Carvalho, M., \& Tippett, N. (2006). An investigation into cyberbullying, its forms, awareness and impact, and the relationship between age and gender in cyberbullying. A Report to the anti-Bullying Alliance. London. UK.

Seals, D., \& Young, J. (2003). Bullying and victimization: Prevalence and relationship to gender, grade level, ethnicity, self-esteem and depression. Adolescence, 38, 735-747.

Sullivan, K. Clearly, M., \& Sullivan, G. (2004). Bullying in secondary School. London, England: Paul Chapman Publishing.

Tass, S. Carroll, A.; Houghton, S. (2012). Rates of cyber victimization and bullying among male Australian primary and high school student. School of Psychology International, 33(5), 533-549l

Tippett, N., Thompson, F., \& Smith, P. K. (2009). Research on cyberbullying: Key findings and practical suggestions. Education.com. Retrieved from http://www.education.com/reference/article/cyberbullying-research/

Strom, P. S., \& Strom, R. D. (2005). Cyberbullying by adolescents: A preliminary assessment. The Educational Forum, 70, 21-36.

Ybarra, M. L., \& Mitchell, K. J. (2007). Prevalence and frequency of internet harassment instigation: Implications for adolescent health. Journal of Adolescent Health, 41, 189-195

Yusoff, M., \& Zin, N. (2013). Exploring suitable emotion-focused strategies in helping students to regulate their emotional state in a tutoring system: Malaysian case study. Electronic Journal of Research in Educational Psychology, 11(3), 717-742

Willard, N. E. (2007). Cyberbullying and cyberthreats: Responding to the challenge of online social aggression, threats, and distress. Champaign, IL: Research Press.

Williford, A., Elledge, L., Boulton, A. (2013) Effects of KIV: An antibullying program on cyberbullying and cubervictimization frequency among Swedish youth. Journal of Psychological Adolescent, 42(6), 820-833.

Zhou, Z, Tang, H, Tian,Y. (2013).Cyberbullying and its risk factors among Chinese high school students School Psychology International, 34 (6), 630-647 